\begin{tabular}{|l|l|l||}
\hline \multicolumn{2}{|c|}{ PublisherInfo } \\
\hline \hline PublisherName & $:$ & BioMed Central \\
\hline \hline PublisherLocation & $:$ & London \\
\hline \hline PublisherImprintName & $:$ & BioMed Central \\
\hline \hline
\end{tabular}

\title{
Freedom of information
}

\begin{tabular}{||l|l|l||}
\hline \multicolumn{2}{|c||}{ ArticleInfo } \\
\hline \hline ArticleID & $:$ & 4293 \\
\hline \hline ArticleDOI & $:$ & $10.1186 /$ ccf-2000-webreport1825 \\
\hline \hline ArticleCitationID & $:$ & webreport1825 \\
\hline \hline ArticleSequenceNumber & $:$ & 34 \\
\hline \hline ArticleCategory & $:$ & Web report \\
\hline \hline ArticleFirstPage & $:$ & 1 \\
\hline \hline ArticleLastPage & $:$ & 3 \\
\hline \hline & & RegistrationDate : 2000-10-13 \\
ArticleHistory & $:$ & OnlineDate $\quad 2000-10-13$ \\
\hline \hline ArticleCopyright & $:$ & Current Science Ltd2000 \\
\hline \hline ArticleGrants & $:$ & \\
\hline \hline ArticleContext & $:$ & 1305444 \\
\hline \hline
\end{tabular}




\section{Overview}

BioMed Central publishes peer-reviewed research across all areas of biology and medicine. All research published on the site is accessible free of charge; articles are peer-reviewed by external reviewers and published quickly online. BioMed Central articles are cited in PubMed and are available in full through the PubMed\%20Centralpermanent archive.

The peer-review process is speeded up by the use of a web-based system for referees to view manuscripts and feed back comments to authors. Medical articles will be published with reviewers' comments and the author's response.

\section{Content}

BioMed Central is supported by many leading scientists and clinicians around the world. 'BioMed Central promises to deliver all primary research without financial and copyright barriers and deserves all our support. Free access to research and the right to distribute work among colleagues will allow scientists to participate in a truly worldwide community of scholars.'

Professor Marc Kirschner, University of Harvard

\section{Other comments}

Daily

\section{Evaluation}

No special requirements 


\section{References}

1. BioMed Central. [http://biomedcentral.com]

This PDF file was created after publication. 